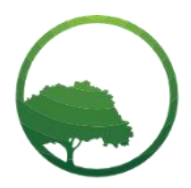

Research in Business \& Social Science

\title{
Financial system, trade concentration and economic growth in West African Monetary Zone (WAMZ)
}

\author{
Nenubari Ikue-John(a), Ifeanyichukwu Lucky Amabuike(b), Joseph Ade Ajaba (c),
} John Akin Sodipo (d), Linus Bamekpari Enegesi (e)

(a) University of Port Harcourt, Nigeria

(b)Nnamdi Azikiwe University,Nigeria

Crossref

(c)Ignatus Ajuru University of Education, Nigeria

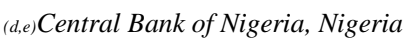

\section{ARTICLE INFO}

Article history:

Received 12 June 2020

Received in rev. form 30 June 2020

Accepted 01 July 2020

Keywords:

Demand-Lending Hypothesis,

Import/Export Concentration and

Financial-Deepening

JEL Classification:

J63, J21, J24, M12, 015, P59

\begin{abstract}
A B S T R A C T
It is observed that despite the legislative endorsement of the West Africa Countries there is still a glaring divergence in economic structures, which impedes the performance to realize macroeconomic convergence and economic growth within the region. This paper investigated the effects of trade and financial indexes in WAMZ on economic growth. The paper uses three variables and a host of control measures to focus on six countries of WAMZ covering the periods of 2001-2018. Given the heterogeneous nature of the information gathered for the study, the models are cast in static and dynamic panel frameworks that provided micro-structure for the combined data analysis. The models were tested with various econometric and statistical instruments. Results from the analysis show that exported trade is highly concentrated to fewer goods, while imported trade is concentrated on more products and partners; that is, countries in WAMZ tend to shadow liberal import policy. The weak link was also noticed among financial and trade indexes and economic growth in the WAMZ economies. The implications call for short term economic plans and policies in the WAMZ economies so as to collectively monitor economic policies and growth. We equally observed that the structures of the economies in the region are heterogeneous making it rather difficult for regional trade and financial indicators to accelerate output growth in the region. Thus our basic postulations are an inter-policy approach on social, political and economic (trade and finance) arrangements that would neutralize the heterogeneity and foster institutional and attitudinal reforms, eliminate insecurity challenges, and spur political stability and responsible leadership within the regions.
\end{abstract}

() 2020 by the authors. Licensee SSBFNET, Istanbul, Turkey. This article is an open access article distributed under the terms and conditions of the Creative Commons Attribution (CC BY) license (http://creativecommons.org/licenses/by/4.0/).

\section{Introduction}

The failure of the post-world war II institutions (Bretton Woods Institution) had heartened and invigorated many economies to seek for alternative institutions that support their economic and political structures. These have led to the drives for alternative institutional arrangements and given births to regional economic integrations in different continents in the globe. Among the various blocs (regional economies), North America, Western Europe, and East Asia have accounted for as much as 80 percent of total outputs of the world economy, (Babones, 2016). The outstanding performances of these regions have stimulated and strengthen economic integration and offers prospects for member states to augment macroeconomic conditions by meeting specific areas, which include trade agreements, inflationary targets, monetary and interests targeting, international investment positions and balance of payment positions, budget deficits, central banks financing and foreign exchange reserves, (Lopez-Cordova \& Moreira, 2003; Kamau, 2010; Bertola, 2010; Ehigiamusoe \& Lean, 2018 and Kizito \& Hooi, 2018).

Almost all the sub-regions in Africa have accepted legislative and institutional reforms to drive and advocate regional economic integration. These were stirred by the experience of the European Monetary Union (EMU) and the respective advantages from large

* Corresponding author. ORCID ID: $x$

(C) 2020 by the authors. Hosting by SSBFNET. Peer review under responsibility of Center for Strategic Studies in Business and Finance. https://doi.org/10.20525/ijrbs.v9i4.770 
production, that helped quicken economic growth and caused poverty alleviation of the regional blocs around the globe (Bhati et al. 2011). The West African Monetary Zone (WAMZ) member states have since 2001, pursued a wide range of economic and financial reforms to settle some of the economic and institutional issues that impede all attempts to achieve trade integration, effective economic interdependence and financial integration. These reforms are integral elements of the whole economic integration of the WAMZ member state as such various related protocols are being implemented to deepen intra-regional trade integration. The integration agenda is anchored on five complementary policies currently pursued by the member states. These policies are the full capital account liberalization; cross-listing of stocks; regional currency convertibility/quoting and trading in the WAMZ currencies; harmonization of financial institutions practices; and cross-border payment systems. Investigations on the progress and the potential benefits of regional economic integrations and the channels through which it can cause economic growth and productivity in member States are tainted in most case, (Campos, Coricelli, \& Moretti, 2018; Ibrahim et al., 2016; Klein and Olivei, 2008; Levine, 2001; Shen et al, 2010; Schularic and Steger, 2010; Dabla-Norris, 2015; ECB, 2017; Gehringer, 2013; Gehringer, 2015; Coulibaly, 2015; and Masten et al., 2008). The existing investigations provided scant results on the influence of financial and trade integration on economic growth among WAMZ member states. It is still uncertain how the different structural reforms chosen to enhance trade and financial integration could affect productivity growth in the WAMZ member states. Given this mixed evidence on the regional integration-economic growth relationship, this paper uses another vista to ascertain the degree to which regional trade and financial measures pursued in WAMZ may have caused the enhancement of output growth. The focus of this paper is on the six countries of WAMZ. The periods of examination covered 2001-2018. The six countries are chosen because of the on-going endeavour in the region to facilitate the establishment of an economic and monetary union among the West African Economy and issues surrounding the Monetary Union (WAEMU) countries in adopting their common currency to the agreed ECO chosen by the ECOWAS region. It is observed that despite the legislative endorsement of the ECOWAS countries there are still glaring divergence in economic structures, which impedes the performance to realize macroeconomic convergence within the region. Because of the heterogeneous nature of the information gathered for the study, the paper make-do with cross-sectional and time series data to examine trade and financial integration impact on economic performances of the WAMZ economies. The combination of the cross-sectional and time series (panel) information controls the heterogeneity which is intrinsic in the combined data. Thus the models are casted in a panel framework that will provide micro-structure for the combined data analysis (Hsiao, 1986). The paper is divided into five sections. Aside from the introductory section, the paper is outlined such that we have issues in literature, data and method of analysis, results and discussions and the conclusion.

\section{Literature Review}

Many literatures have pinpointed to the development of financial integration, sound financial institutions, markets and market infrastructure interconnectivity are some of the medium through which economic integration can impact growth. These literatures have also identified direct or indirect ways that economic blocs affect trade, financial institution, standard of livings and productivity growth within the economies in the blocs, (Lopez-Cordova \& Moreira, 2003; Kamau, 2010; Bertola, 2010; Cornia, 2011; Gao, 2011; Eichengreen, 2012; Gehringer, 2013; Conti, 2014; Geda \& Kebret, 2014; Schonfelder \& Wagner 2015; Janus \& Riera-Crichton, 2015; Konig, 2015; Mann, 2015; Anyanwu, 2015; Busemeyer \& Tober, 2015; Mevel et al., 2016; Roy \& Mathur, 2016; Kalaitzoglou \& Durgheu, 2016; Soete and Hove, 2017; Baier et al., 2017; Jooji \& Oguchi 2017; ECB, 2017; Klofat, 2017; Ehigiamusoe \& Lean, 2018 and Kizito and Hooi, 2018). In a specific term Jones (2002) used a mixture of cross-sectional units and time series data to test for intersection in ECOWAS nations spanning from 1960-1990. The work revealed that there is a likelihood that per capita income would intersect in the ECOWAS region.

Using a panel of 15 and 17 member states of the European Union over the period 1960-1998, Cuaresma et al (2008) and Conti (2014) opined that the duration of EU membership has a positive and non-symmetric impact of economic integration on economic growth in the long-run. Kamau (2010) observed a significant impact of the economic integration indicators on economic growth especially for countries in the Common Market, for East and Southern Africa (COMESA), East Africa Community (EAC) and Southern Africa Development Community (CADC) trade blocs. While other literature revealed mixed evidence on the growth effect of economic integration. As the works of Kalaitzoglou \& Durgheu (2016) observed no straight forward impact, neither in the political nor financial integration on economic growth in EU countries. Their study, however, reveals that monetary integration has a dual and direct impact on economic growth in EU member countries.

Taking into cognizance, the empirical literature on the channel reveals inconclusive evidence on the impact of financial integration on productivity and economic growth. While there are proof supporting the significant impact of financial integration on economic growth (Ibrahim et al., 2016; Klein \& Olivei, 2008; Levine, 2001; Sen et al, 2010; Schularic and Steger, 2010), Levine (2001) illustrates that the license of restrictions on foreign portfolio inflows as it encourages the involvement of international banks will increase the efficiency and stimulate development of the local financial system, as it will also improve economic growth by increasing productivity growth. Klein \& Olivei (2008) employed the IMF's standard of Exchange Arrangements and Exchange Restrictions as a nexus for capital account liberalization (financial integration), their work revealed a significant and positive impact of capital account liberalization on growth in the economy for the representation of countries covered in the study. A similar conclusion on the significant influence of financial integration on economic growth is obtained in Schularic \& Steger (2010). In the same vein, Ibrahim et al. (2016) find positive impact of foreign financial integration on economic growth. Shen et al (2010) consider two levels of foreign capital inflows as nexus for financial integration (foreign direct investment and foreign portfolio investments) using a panel data of 
80 nations. They concluded that foreign direct investment causes a significant and positive impact on regional economic growth, whereas foreign portfolio investments highlight a non-positive influence on economic growth. Gehringer (2013) having employed two degree levels of financial openness as nexus for financial integration, applying the IMF data on Exchange Arrangements and Exchange Restrictions to build an indices of financial integration as well as employing principal components deduction, and another measure recorded as the extent of stock of total liabilities to GDP, observed that financial openness have an intense significant impact on economic growth, productivity growth and capital accumulation. At the lower point, the result recommends an exact mixed picture on the impact of financial integration on productivity.

The spirited works by Lopez-Cordova \& Moreira (2003) showed that the availability of international firms have had a serious influence on both the producers and consumers in Mexico. In Brazil, the case is however different which reveals an insignificant general impact on the degree of productivity as well as a negative effect on productivity growth. Other scholars found proof recommending that the presence of multinationals companies in host countries can create a bandwagon effect in the area of technology advancement (e.g. Javorcik, 2004). In a similar vein, Gehringer (2015) finds positive productivity effects of financial integration. Whereas, between the manufacturing and services sectors, there are various productivity degrees of impact. One problem oversight in the previous works is the fact that some of the correlation among financial integration, productivity as well as economic growth may not be linear as assumed by many scholars, but might also rely heavily on the institutional quality as well as the degree of development. A few studies have echoed such thoughts, and their results completely recommend that the impact of growth might rely on the extent of the development in the financial markets. Masten et al. (2008) have utilized a threshold modelling technique to investigating if there are nonlinearity and threshold impacts of financial development as well as foreign financial integration on economic growth. The study shows significant nonlinear effects and illustrates that the influence of financial integration relies heavily on the degree of development in the financial sector. Coulibaly (2015) arrives at an exact deduction, using the unrestricted panel transition degree of association method on the sub-Saharan Africa countries as sample; illustrated that the minimal influence of financial integration on growth relies on the degree of financial development, the institutional quality as well as the level to trade openness. While Ibrahim et al. (2016) discovered a significant impact of financial integration on economic growth, the correlation seems not to be true within nations that has low degrees of development and among the most developed nations. The authors underscore the various perspectives of other literature on the subject matter that indigenous absorption capacity is very necessary in allowing nations to receive from financial market integration. Henrekson, et al., (1997) examine the role of trade and institutional integration on economic growth, using a purely empirical approach on European Community (EC) and European Free Trade Area (EFTA) countries along with a sample of OECD countries. Using cross-sectional and pooled OLS study, their study finds that joining the EU or EFTA enhances growth. Crespo-Cuaresma, et al., (2002) examine the impact of European integration on economic growth of current EU members, using a panel regression. They find that the length of EU membership has a significant and positive effect on growth, and it is higher for poorer countries, suggesting an asymmetric impact of EU membership.

Martin and Velázquez (2001), Wagner and Hlouskova (2002) and Boldrin and Canova (2003) provide a descriptive analysis of how different experiences of convergence of the recent EU members affected economic growth after joining the EU and derive lessons from these countries' experience for the candidate countries. Employing different growth scenarios, they examine the beneficial effects of the EU membership and how long it would take for the candidate countries to fully complete the convergence process. They emphasize the importance of national policies to achieve a sustained period of significant growth above EU averages and hence real convergence towards the EU standards. At the macro-level, there is evidence suggesting the positive effect of trade integration on productivity growth. As the work of Dabla-Norris et al. (2015) using aggregate productivity growth data to investigate the structural reforms impact on productivity growth, the findings of the results show trade liberalization to be an accelerator to productivity growth in the lesser income nations. At the firm level, the work of ECB (2017) engages a panel static impacts model with a sample size of 13 manufacturing firms to examine the impact of foreign trade, through the imports and exports channels and global value chains related trade on productivity among 40 nations (emerging and advanced nations). The results signal a strong positive effect of foreign trade on labour productivity. Similarly, Lopez-Cordova \& Moreira (2003) finds strong trade related gains especially through imports. Rajan-Zingales (2003) assumed that the alliance of trade and financial liberalization is the first order condition for the achievement of regional economic integration (trade and financial development), because it tends to push up output growth.

\section{Research and Methodology}

\section{Data}

Seven variables are used in this study. They are total output growth of the economies (proxy as log of GDP at current U.S. Dollar (grit)), financial system soundness index (proxy as the ratio of private credits to deposit Money Banks and other financial institutions to nominal GDP(fdit)), trade participation (proxy as export concentration index (eiit) and import concentration index (imit)); institutional quality (proxy as the index of corruption perception (iqit), ), level of domestic prices in the respective countries (dpit) and issues of currency convertibility (we used the exchange rates of the respective country currencies to the US Dollar to proxy as currency convertibility index (ccit)). The data are sourced from the Penn world tables, World Bank's Governance indicators, the IMF database online and the World Bank's World Development Indicators (WDI). 
Table 1: Statistical Structure of Data for the Six Countries

\begin{tabular}{|c|c|c|c|c|c|c|c|c|}
\hline & & gr & fd & ei & im & iq & dp & cc \\
\hline \multirow[t]{4}{*}{ POOLED DATA } & MEAN & 125849.70 & & 0.50 & 0.25 & 25.33 & 13.58 & 1562.34 \\
\hline & STD & 255755.60 & & 0.19 & 0.23 & 15.48 & 14.87 & 2504.18 \\
\hline & MAX & 971995.30 & & 0.92 & 0.86 & 59.33 & 100.63 & 9125.74 \\
\hline & MIN & 1660.81 & & 0.19 & 0.06 & 0.51 & -3.92 & 0.54 \\
\hline \multirow[t]{4}{*}{ GAM } & MEAN & 4432.71 & 7.32 & 0.32 & 0.14 & 31.34 & 8.72 & 30.74 \\
\hline & STD & 702.70 & 1.96 & 0.08 & 0.01 & 7.21 & 13.18 & 9.95 \\
\hline & MAX & 5754.76 & 10.65 & 0.49 & 0.16 & 46.97 & 60.70 & 46.61 \\
\hline & MIN & 3316.69 & 4.62 & 0.19 & 0.11 & 21.63 & 1.81 & 12.79 \\
\hline \multirow[t]{4}{*}{ GHA } & MEAN & 97322.38 & 12.17 & 0.43 & 0.09 & 53.11 & 23.56 & 1.87 \\
\hline & STD & 33755.69 & 4.05 & 0.05 & 0.02 & 4.39 & 17.16 & 1.39 \\
\hline & MAX & 149846.90 & 17.85 & 0.51 & 0.14 & 59.33 & 80.75 & 5.02 \\
\hline & MIN & 56458.87 & 6.49 & 0.33 & 0.06 & 43.90 & 10.21 & 0.54 \\
\hline \multirow[t]{4}{*}{ GUI } & MEAN & 20605.30 & 4.85 & 0.52 & 0.17 & 14.93 & 13.55 & 5278.13 \\
\hline & STD & 4460.10 & 2.87 & 0.07 & 0.03 & 5.31 & 22.33 & 2557.81 \\
\hline & MAX & 29814.27 & 9.69 & 0.64 & 0.23 & 29.80 & 100.63 & 9125.74 \\
\hline & MIN & 15624.24 & 2.26 & 0.41 & 0.11 & 6.80 & 0.43 & 1746.87 \\
\hline \multirow[t]{4}{*}{ LIB } & MEAN & 3027.02 & & 0.54 & 0.71 & 21.47 & 11.01 & 1.00 \\
\hline & STD & 539.44 & & 0.15 & 0.11 & 11.65 & 4.38 & 0.00 \\
\hline & MAX & 3679.73 & & 0.82 & 0.86 & 37.86 & 23.56 & 1.00 \\
\hline & MIN & 1660.81 & & 0.33 & 0.54 & 2.54 & 6.83 & 1.00 \\
\hline \multirow[t]{4}{*}{ NIG } & MEAN & 622068.80 & 12.01 & 0.83 & 0.11 & 10.73 & 12.05 & 162.38 \\
\hline & STD & 301284.50 & 3.75 & 0.05 & 0.04 & 4.47 & 3.76 & 60.81 \\
\hline & MAX & 971995.30 & 20.16 & 0.92 & 0.23 & 19.42 & 18.87 & 307.13 \\
\hline & MIN & 119407.90 & 7.52 & 0.74 & 0.06 & 0.51 & 5.38 & 101.70 \\
\hline \multirow[t]{4}{*}{ SLE } & MEAN & 7642.05 & 4.16 & 0.35 & 0.29 & 20.42 & 12.57 & 3899.89 \\
\hline & STD & 2263.94 & 1.76 & 0.13 & 0.11 & 3.99 & 15.76 & 1670.61 \\
\hline & MAX & 10938.45 & 6.85 & 0.70 & 0.37 & 31.25 & 73.84 & 7384.43 \\
\hline & MIN & 4335.88 & 1.32 & 0.20 & 0.09 & 13.66 & -3.92 & 1986.15 \\
\hline
\end{tabular}

Source: Authors Computation, (2020)
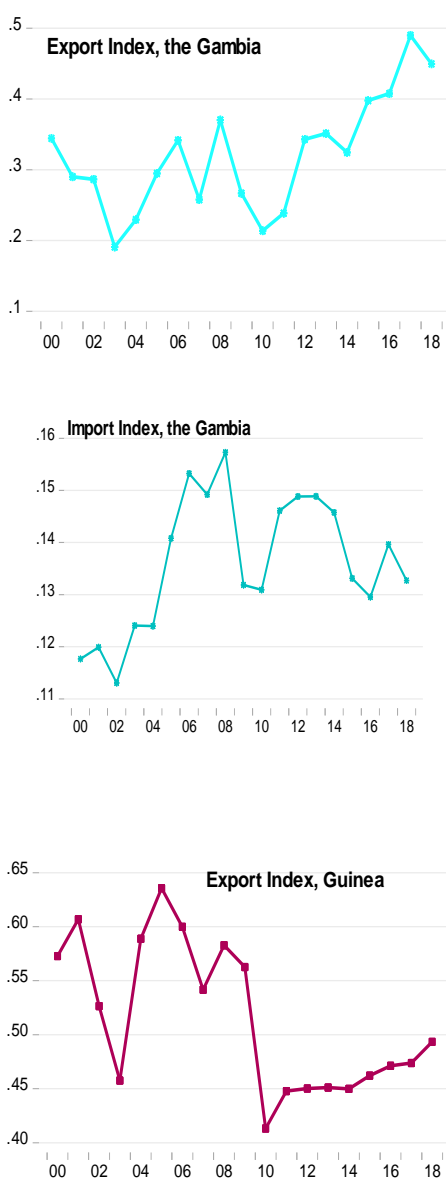
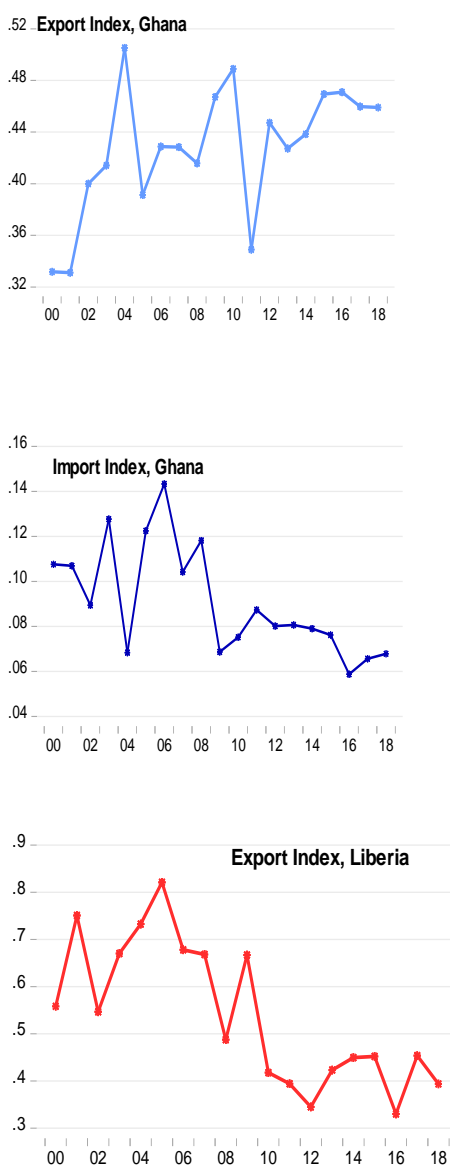

Figure 1: Graphical Illustration of Imports and Exports Concentration Index across Countries; Source: Authors Computation, (2020) 

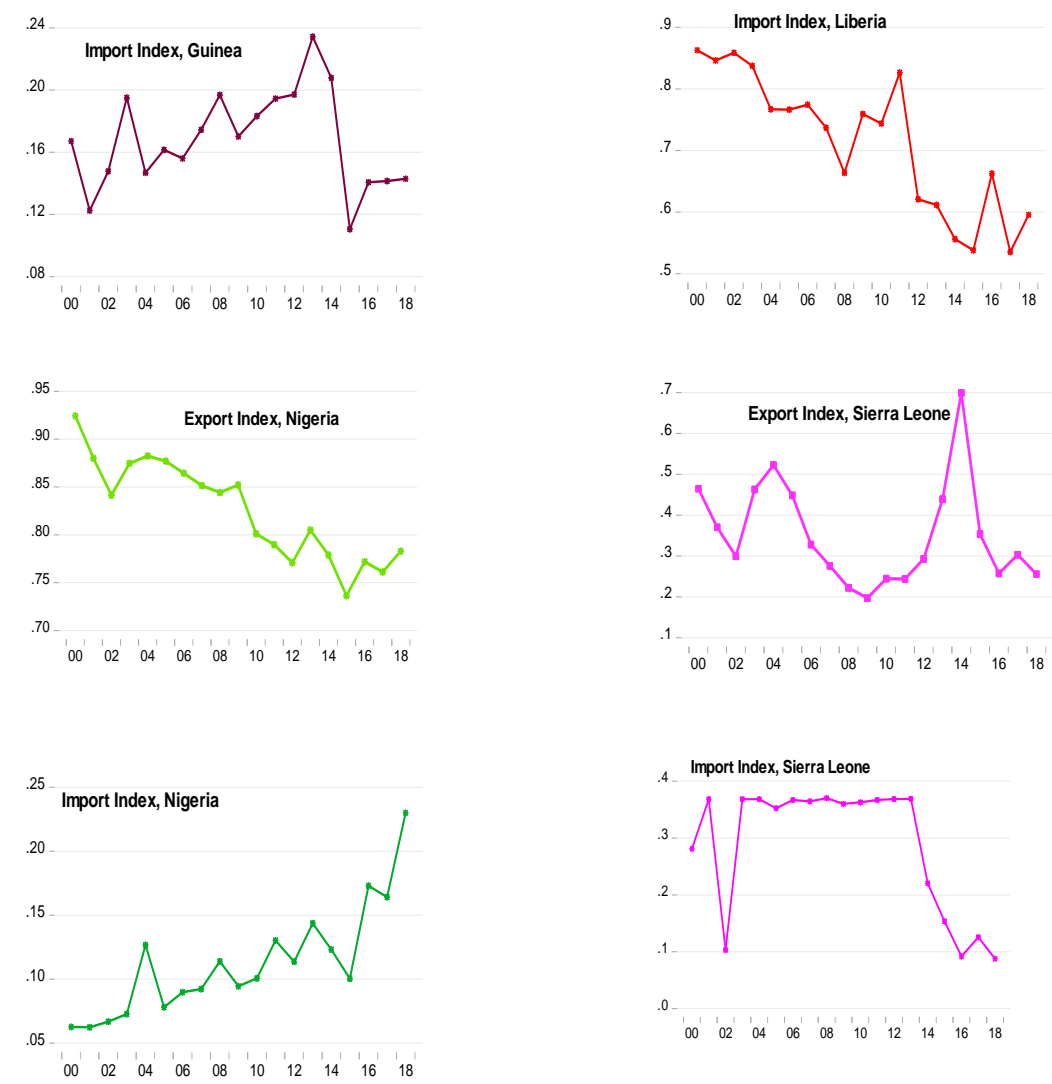

Figure 1 (Cont'd): Graphical Illustration of Imports and Exports Concentration Index across Countries; Source: Authors Computation, (2020)
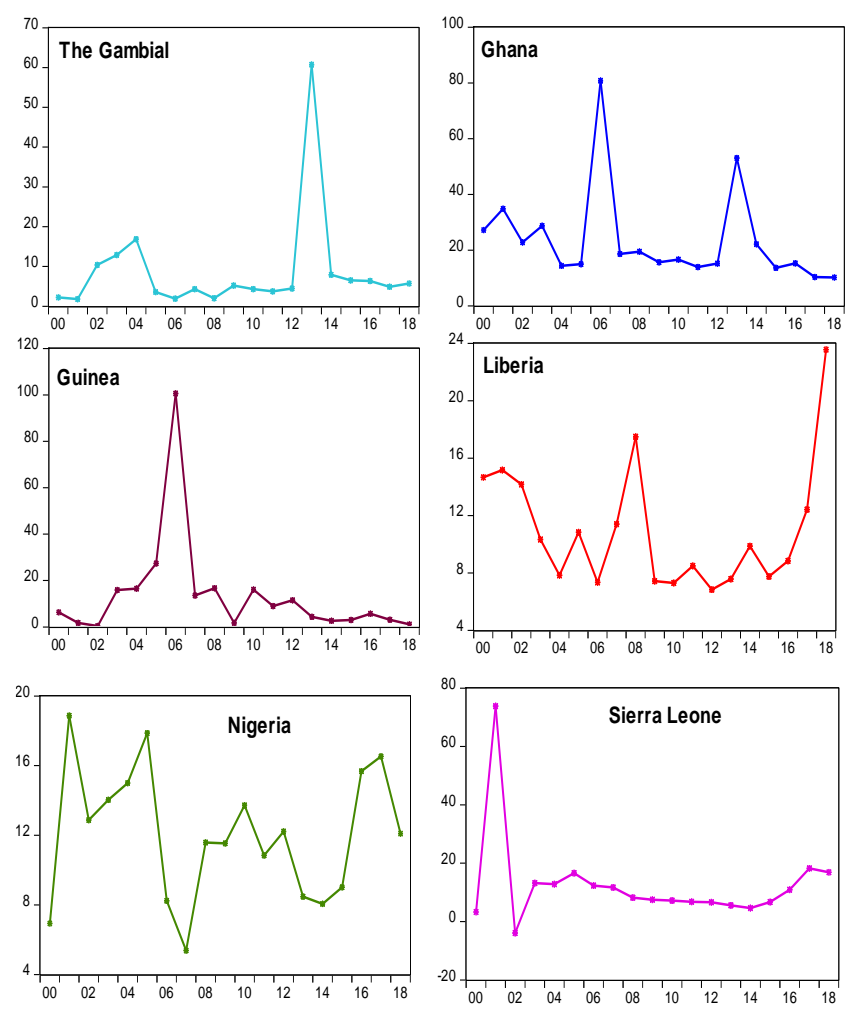

Figure 2: The Nature of Domestic Prices in the Selected Economies 


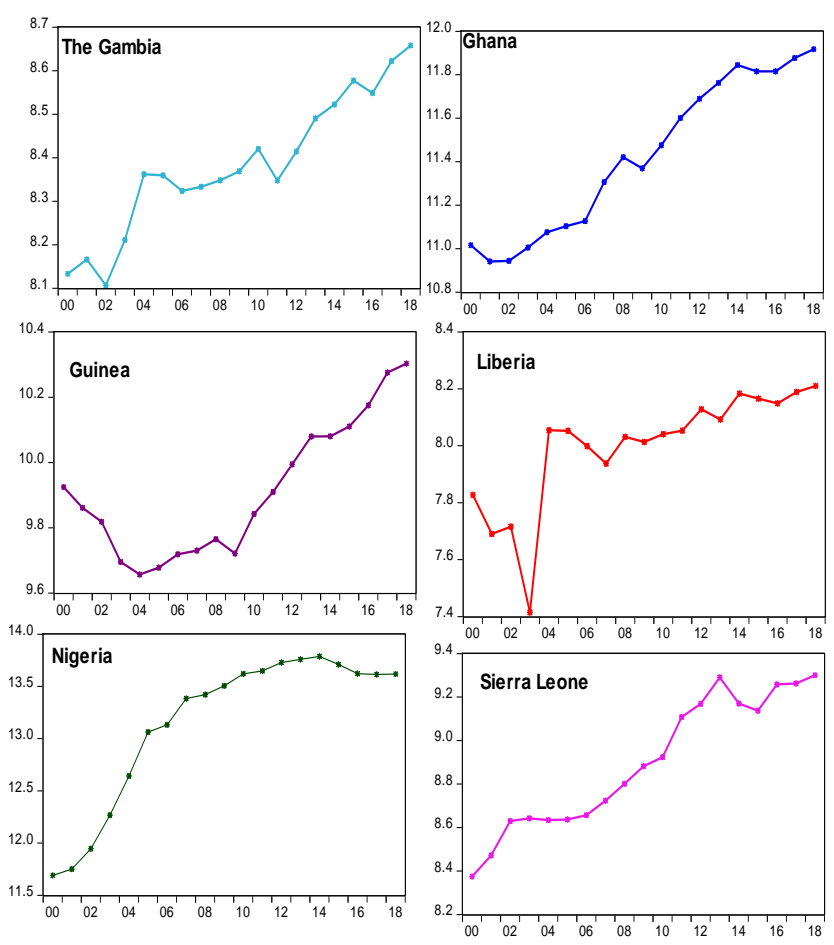

Figure 3: The Nature of Economic Growth in the Selected Economies

The summary statistics for selected variables and indicators is reported on Table 1. The average size of the six countries is less than the average of the Nigeria economy for the $17_{\text {th }}$ periods examined. The largest economy in the group is Nigeria and Liberia is the smallest economy. The performance of the financial indicators in Nigeria tend to perform better than others. However, the Ghanaian economy is proving to be more competitive with an average of double digits of financial deepening. The contribution financial system efficiency or soundness' to total outputs of the region is very weak, as it averages only about $12 \%$ for the stronger economies within the region in the $17_{\text {th }}$ year.

The tendency for corruption in institutions is tolerated more in Ghana and Gambia economies, than other countries in the group. Liberia had pegged their currency to the U.S. Dollar, but have the worst financial system development among the countries selected for the study. The issues of trade, domestic prices and the nature of economic growths for the countries are demonstrated on figures 1,2 and 3 respectively. We observed that exports in the region are highly concentrated to fewer goods, while import is concentrated to more products and partners. The indices revealed that trade and financial integration within the region performed below average.

\section{The Models}

$g r_{i t}=f\left(f d_{i t}, e i_{i t}, i m_{i t}, i q_{i t}, d p_{i t}, c c_{i t}\right)$

\section{Random Effect Specification}

$Y_{i, t}=X_{i, t}^{\prime} \beta+\delta+\mu_{i}+\pi_{i, t}$

Where

$Y_{i, t}$ is vector of dependent variable $\left(g r_{i t}\right)$

$X_{i, t}^{\prime}$ is matric of independent variables $\left(f d_{i t}, e i_{i t}, i m_{i t}, i q_{i t}, d p_{i t}, c c_{i t}\right)$

$\delta$ represents the common intercept across countries and the disturbance term is $\varepsilon_{i, t}=\mu_{i}+\pi_{i, t}$.

\section{Fixed Effect Model}

$Y_{i, t}=X_{i, t}^{\prime} \beta+\varepsilon_{i, t}$

$\varepsilon_{i, t}=\alpha_{i}+\gamma_{t}+\eta_{i t}$

Where

$\alpha_{\mathrm{i}}$ is the unobserved cross sectional specific effects

$\gamma_{\mathrm{t}}$ is the unobserved time specific effects 
$\eta_{\text {it }}$ is the common cross section time series effect

$Y_{i, t}$ is the dependent variable in the models;

$X_{i, t}^{\prime}$ refers to the matrix of the independent variables and control variables in the models

$\delta y_{i, t-1}=$ Catch - up effects in model 3

\section{Dynamic Specification}

The panel dynamic model is casted as follow

$$
y_{i, t}=\delta y_{i, t-1}+X_{i, t}^{\prime} \beta+\mu_{i}+\omega_{i, t}
$$

Precisely, the models are reported in static and dynamic specifications and casted in matric form.

The fixed and random effects specification, (static specification), emphasizes the issues of heterogeneity and homogeneity inherent in cross-sectional time series data. The error component $\left(\varepsilon_{i, t}\right)$ of the random effects models are sometimes decomposed into two parts: the fixed part, $\delta$, representing the population average and $\mu_{i}$ representing the random difference. $\mu_{i}$ is the random heterogeneity particular to the cross-section information or observation (country effect) which is not dependent on time (constant through time), that is, $\mu_{i} \neq X_{i, t}^{\prime}$, whereas in the Fixed effect model, $\mu_{i}=X_{i, t}^{\prime}$. That is all behavioural difference between individual countries, referred to individual heterogeneity, and are suggested to be absorbed by the intercept in the Fixed Effect. This separate effects or intercept are addressed as variables since it accounted for the variance among countries, (Olubusoye, Salisu, \& Olufin, 2015).

The robust test statistics of constant variance in the error across heterogeneity by Levene, (1960) and Brown \& Forsythe (1974) was employed to select the estimator for the static model and was later verified by the procedure of the Baltiga (2001) test on the intercept heterogeneity on the coefficients. The Baltiga test is used to test for homogeneity of the intercept, as such it was chosen over the Hausman spirited test. The test results are reported on table 3.

The dynamic specification is described by introducing the lags of the functional variable (catch-up effect) into the static model. The introduction of the lags of the dependent variable into the equation sometimes lead to the prevalence of autocorrelation $\left(i . e ., y_{i, t}=\right.$ $\omega_{i, t}$, whereas we expected that $\left.y_{i, t} \neq \omega_{i, t}\right)$.

Applying the estimators of equation (2) and (3) will yield bias estimate and inconsistent parameter even if the $\omega_{i, t}$ is serially correlated, (Baltagi, 2008). To account for the scenario painted above and then estimate the static and dynamic behaviour of economic relationship among the variables used in this paper, the "ibn command" in STATA was used for the estimation of the static model and methods of Arellano and Bond (1991), Generalized Methods of Moment (GMM) also called the difference GMM for the dynamic model (Arellano-Bover, 1995; Davidson \& Mackinnon, 2004; Bun \& Windmeijer, 2009; Alege \& Ogundipe 2013; Olubusoye, et al., 2015; Medee \& Ikue-John 2017; Ikue-John, \& Nkoro, 2019).

\section{Results and Discussions}

The variables were pooled and estimated with the Ordinary Least Square (OLS). The outcome shows that the estimates are correctly signed and significant with an impressive $\mathrm{R}_{2}$, adjusted $\mathrm{R}_{2}$ and highly significant F-Statistics. The acceptability of the model was contested with the levene, (1960) and Brown \& Forsythe (1974) robust test statistics of constant variance in the error across units, (the hypothesis of the test argued that the Variance across units are equal, see table2).

The three statistics or trimmed mean (W0, W50 and W10) could not ascertain the acceptability of the model irrespective of the impressive estimates (theoretical confirmations) and diagnostics. The likelihood of equality of variance across units is rejected by the significance of the trimmed mean. That is, the coefficients (country specific effects varies across unit) of the individual unit account for great deal in the analysis of the six counties in the WAMZ.

Table 2: Summary Statistics for test of pooled Regression

\begin{tabular}{|c|c|c|c|c|c|}
\hline Code & Mean & Std. Dev. & Freq. & Test Statistics & \\
\hline $101 \equiv$ GAM & -0.8749 & 0.4582 & 19 & $\mathrm{~W} 0=6.7950 d f(5,123)$ & $\operatorname{Pr}>\mathrm{F}=0.0000$ \\
\hline $102 \equiv$ GHA & 0.4524 & 0.3857 & 19 & & \\
\hline $103 \equiv$ GUI & -0.3875 & 0.6564 & 19 & & \\
\hline $104 \equiv \mathrm{LIB}$ & -0.1537 & 0.8276 & 19 & $\mathrm{~W} 50=5.6539 d f(5,123)$ & $\operatorname{Pr}>\mathrm{F}=0.0001$ \\
\hline $105 \equiv \mathrm{NIG}$ & 0.7315 & 1.1047 & 19 & & \\
\hline $106 \equiv \mathrm{SRL}$ & 0.2322 & 1.0444 & 19 & & \\
\hline Total & $3.740 \mathrm{e}-16$ & 0.9457 & 114 & $\mathrm{~W} 10=6.9824 d f(5,123)$ & $\operatorname{Pr}>F=0.0000$ \\
\hline
\end{tabular}

** and *** implies statistical Significance of $5 \%$ and $1 \%$ respectively

Source: Estimated from STATA 13.0 
Table 3: Test Random Effects and Fixed Effects Estimators

\begin{tabular}{lll}
\hline Variable & Coefficient & Prob. \\
\hline 101-GAM & $7.8572 * * *$ & 0.0000 \\
\hline 102-GHA & $10.6965^{* * *}$ & 0.0000 \\
\hline 103-GUI & $9.0076^{* * *}$ & 0.0000 \\
\hline 104-LIB & $6.8857^{* * *}$ & 0.0000 \\
\hline 105-NIG & $12.8515 * *$ & 0.0000 \\
\hline 106-SRL & $7.9869^{* * *}$ & 0.0000 \\
\hline Model Diagnostic for the Testparm Unit Test & \\
\hline Test Statistics & 281.48 & Prob $>\boldsymbol{F}=0.0000$ \\
\hline F(6, 102) $=$ &
\end{tabular}

Source: Estimated from STATA 13.0

The estimates of constant properties of the individual units are reported in table 3 which are elastic and statistically significant. The Baltiga (2001) conformation test on the intercept heterogeneity indicates that they are heterogeneous. The result explicit the diversity or differences of monetary (financial), fiscal (government) and trade (external) policies among the WAMZ countries as well as the different layers of political, socio-economic, geographical and demographic structures among them (weak harmonization or coordination macroeconomic of policy). Scholars like Ibraham (2016) have shown that diversity of institutional quality plays major role in economic and financial integration and that countries with weaker financial institutions (less developed financial markets) have weaker degree of economic and financial integration. The significance of the intercept coefficients emphasises that strengthening the quality of institutions and policy harmonization in and across individual economies and region can stimulate regional economic outputs.

Table 4: Summary of Static and the Dynamic Models

\begin{tabular}{|c|c|c|c|}
\hline Variable & OLS & FE & GMM \\
\hline$d g r_{i t-1}$ & - & - & $0.8892 * * *$ \\
\hline$C_{i t}$ & $6.5423 * * *$ & $9.2142 * * *$ & 0.5722 \\
\hline$f d_{i t}$ & 0.0005 & 0.0005 & 0.0003 \\
\hline$e i_{i t}$ & $7.2706 * * *$ & 0.1091 & 0.6041 \\
\hline$i m_{i t}$ & $-4.5594 * * *$ & -0.8227 & -0.7598 \\
\hline$i q_{i t}$ & $0.0311 * * *$ & $0.0129 * *$ & -0.00001 \\
\hline$d p_{i t}$ & 0.034 & -0.0035 & - \\
\hline$c c_{i t}$ & 0.0001 & $0.0001 * * *$ & - \\
\hline$R_{2}$ & 0.7420 & 0.9989 & - \\
\hline$A d j \_R 2$ & 0.7275 & 0.9988 & - \\
\hline F-statistic & $51.28 * * *$ & $8072.97 * * *$ & - \\
\hline$A R(1)$ & - & - & $-2.12 * *$ \\
\hline$A R(2)$ & - & - & 1.12 \\
\hline Hansen J-Test & - & - & $1.3211[0.2012]$ \\
\hline Obs. & 114 & 114 & 102 \\
\hline
\end{tabular}

** and $* * *$ implies statistical Significance of $5 \%$ and $1 \%$ respectively

The lag of economic growth (Catch-Up effects) in the dynamic model show a significant cluster effects of lagged dependent variable. The regional outputs internally validated itself to future output path; it perpetuates itself relatively and attracts further growths because foreign investors can locate or perceived growth regions and pushed for new investment see Moses \& Godbertha (2012) and Krugell (2005). We observed that financial system development related positively to output progressively in both the static and dynamic models. The parameter is insignificant (that is, underdevelopment of the financial system (market) in the region is responsible for weaker economic growth of the WAMZ economies, the nature of responsiveness of economic growth of the region to financial system is perfectly inelastic (one per cent improvements in the integration of the financial system of the six countries will lead to minor improvement in economic growths of the region). The result establishes the opinions of theories, that development of the financial system will enhances positive regional economic integration and growths. The result also corroborated with other empirical literature (Cuaresma et al 2008; Klein \& Olivei, 2008; Masten et al., 2008; Kamau 2010; Sen et al, 2010; Gehringer 2013; Conti 2014; Gehringer 2015; Coulibaly, 2015; and Ibrahim et al., 2016) whose findings supported a positive relationship between various financial integration indexes and regional economic growths. Empirical evidence in the European region shows stronger implications of financial integrations on economic growths of the region, than we observed in the WAMZ region. The glorious stories in EU as 
stated by scholars are the highly developed financial market in individual economies. The magnitudes or rates of responsiveness in the European models are direct, elastic and fairly inelastic, emphasising individual countries financial soundness, (Kalaitzoglou \& Durgheu 2016). Masten et al. (2008) Coulibaly (2015) had shown nonlinear effects of financial integration indexes on economic growth in Africa and argued an inelastic coefficient as ours and traced it to the underdeveloped financial markets of majority of the Africa economies. The results obtained here only demonstrated the potentialities of financial system dynamics on improving the output growths of the WAMZ economies, and can only be achieved by a strong advancement in the individual countries financial markets. The theoretical assumption is that enhancement of the export and import concentration in the region tend to spark or trigger economic growth. The observed exact relationship indicated that those economies in the region are mono-product oriented (largely primary commodities) exporters mostly in the short term period. Our result slightly differs from findings like (Anyanwu, 2015; Mevel et al, 2016 and Baier et al. 2017). The argument from those authors underlined that in West, North and East Africa, positive strong link exist between trade index and economic integration, but that there are differences in the trade proxies between the present study and those works. For instance, some employed degree of trade openness as the variable that equates trade integration index while others used the aggregate monetary value of imports and exports. The different in variables may leads to the models showing positive relationship of their work in the long run. On the institutional quality, our results differed from Schonfelder \& Wagner (2015). They positioned that strong institutional development granger cause growth within the Europeans economies, whereas in the African environment (economic regions) the reverse holds in our findings.

\section{Conclusions}

The findings of this study indicated internal validity on the basis that strong financial sector of the WAMZ economies and the index of trade volume as the basic components of regional integration are sacrosanct to high volume of economic growth within the region. The basic findings revealed weak link among financial and trade indexes and economic growth in the WAMZ economies. The implications call for short term economic plans and policies in the WAMZ economies so as to collectively monitor economic policies and growth. WAMZ economies promptly follow liberal import policy that is demand-leading hypothesis. Therefore, this work pinpointed that the sampled economies in the WAMZ exhibit heterogeneous relationship making it difficult for economic integration within the WAMZ economies to support intensive growth. Based on the foregoing, WAMZ economies should support more aggressive financial liberalisation policies so as to allow financial flows and output as the financial integration co-efficient support growth in both the static and dynamic models. We argued that the other sampled economies within the WAMZ to understudy the financial market arrangement in Nigeria and Ghana, in other to improve their financial market and encourage regional economic integration as well as total output in the zone. It is paramount to set financial service authority (or strengthen the existing once, e.g. WAIFEM through legislative engagement) that monitors the actions of the financial institutions and as well provide the needed information that facilitates robust and sound regional financial and economic integrations and outputs. This will encourage and improve the activities of the economies to enhance outputs more especially in this period of epidemic and global economic crises. Also the need to limit imports and encourage export through import substitution strategies or quota or outright bound on some selected commodities. In this regards, Africa countries have nothing to lose since their exports are mostly primary commodities which elasticity depicts to be demand necessities. The study urges countries in the WAMZ to discourage the imports of primary (Agricultural Produce-Rice) goods. Thus, our basic postulations are inter-policy approach on social, political and economic arrangements that will neutralize the heterogeneity and foster institutional and attitudinal reforms, eliminate insecurity challenges, and spur political stability and responsible leaderships.

\section{References}

Alege, Philip O. \& Ogundipe, Adeyemi A. (2013). Foreign Direct Investment and Economic Growth in ECOWAS: A systemGMM Approach Covenant. Journal of Business and Social Sciences, (CJBSS); 5(1).

Arellano, M. B. S. Bond. (1991). Some Tests of Specification for Panel Data: Monte Carlo Evidence and Application to Employment Equation, Review of Economic Studies. 58(11), 277-97.

Arellano M. O. Bover (1995). Another Look at the instrumental variable estimation of error components models. Journal of Econometrics. 6(8), 29-51.

Anyanwu, J. C., ((2015). Estimating the macroeconomic effects of monetary unions: the case of trade and output. African Development Review, 15, pp.126-145.

Babones, S., (2016). The regional structure of the global economy: Economic hierarchies and growth strategies. Sydney: Salvatore Babones Newsletter; University of Sydney.

Baier, S. L., J. H., Bergstrand, P. Egger, and P. A., McLaughlin, (2017). Do economic integration agreements actually work? Issues in understanding the causes and consequences of the growth of regionalism. The World Economy, 31(1); pp. 461-497.

Baltagi, B. H., (2001. Econometric Analysis of Panel Data, 2nd ed., John Wiley and Sons accompanying website http://www.wiley.com/legacy/wileychi/baltagi.

Baltagi, B.H., Demetriades, P. \& Law, S.H., (2008). Financial development, openness and institutions: evidence frompaneldata. Discussion Paper No. 07/5. University of Leicester.

Bertola, G., (2010). Inequality, integration, and policy: issues and evidence from EMU. The Journal of Economic Inequality, 8, pp. $345-365$. 
Bhati, R. J., Zhang, J., \& Kiptoo, C. K., (2011). Facilitating Multilateral Fiscal Surveillance in a Monetary Union Context with Focus on COMESA Region. COMESA and African Development Bank.

Brown, M. B., Forsythe, \& Alan B., (1974). Robust tests for the equality of variances. Journal of the American Statistical Association. 69: 364-367

Bun, M. J., \& Windmeijer, F. (2009). The Weak Instrument Problem of the System GMM Estimator in Dynamic Panel Data Models. The Tinbergen Institute for economic research of the Erasmus Universiteit Rotterdam (pp. 1-50).

Amsterdam:Universiteit van Amsterdam, and Vrije Universiteit.

Busemeyer, M. R. and T. Tober, (2015). European integration and the political economy of inequality. European Union Politics, 16, pp. 536-557.

Campos, N. F., F. Corricelli and S. Morretti, (2018). The impact of Brexit on the UK inward FDI. Economics, management and sustainability. 3(1); 6-20.

Conti, M. (2014). The introduction of the Euro and economic growth: Some panel data evidences. Journal of Applied Economics, $17(1) ; 199-211$.

Cornia, G. A., (2011). Economic integration. inequality and growth: Latin America versus the European economics in Transition. Review of Economics and Institution, 2(2); 1-31.

Coulibaly, I., (2015). Optimality of a monetary union: New evidence from exchange rate misalignments in West Africa. Economic Modelling, 32(2); 463-482.

Crespo-Cuaresma, J. A S. Maria, and R. Doris, (2002). Growth, convergence and EU membership. Applied Economics. 40(5): 643- 656.

Dabla-Norris, E., Ho, G., \& Kyobe, A., (2015). Structural Reforms and Productivity Growth in Emerging Market and Developing Economies. IMF Working Paper WP/16/15.

Davidson, R., MacKinnon, J.G. (2004). Econometric Theory and Methods; Oxford University Press.

European Central Bank (ECB), (2017). Statement by Mario Draghi, President of the ECB, at the thirty-fifth meeting of the International Monetary and Financial Committee. Washington DC, 21 April 2017 European Central Bank

Eichengreen, B., (2012). European monetary integration with benefit of hindsight. Journal of Common Market Studies, 50(1); 123136.

Ehigiamusoe, K. U., \& Lean, H. H. (2018). Doe economic and financial integration stimulate economic growth? A critical survey. Economics-The Open-Access, Open-Assessment E-Journal, 13, 1-27.

Gao, T., (2011). Foreign direct investment and growth under economic integration. Journal of International Economics, 67(1); 157-174.

Geda, A. and H. Kebret, (2008). Regional economic integration in Africa: A review of problems and prospects with a case study of COMESA. Journal of African Economies, 17(1); 357-394.

Gehringer, A. (2013). Growth, productivity and capital accumulation: The effects of financial liberalization in the case of European integration, International Review of Economics and Finance, 25, pp. 291-309.

Gehringer, A. (2015). Uneven effects of financial liberalization on productivity growth in the EU: Evidence from a dynamic panel investigation, International Journal of Production Economics, 159, pp. 334-346.

Henrekson, M., J. Torstensson, and R. Torstensson, (1997). Growth effects of European integration. European Economic Review, 41: 1537-1557.

Ibrahim, S., A. R., Mazlina, W.N.W. Azman-Saini. and M. F. M. Zakaria, (2016). Financial integration-growth nexus: A Quantile Regression Analysis. Journal of Economic Integration, 31(3): 531-546.

Ikue-John N. \& E, Nkoro, (2019). Dynamics of Capital Adequacy and Profitability of Internationalized Deposit Money Banks in Nigeria. BUSSECON Review of Finance \& Banking 1(1) 18-2. https://doi.org/10.36096/brfb.v1i1.96

Janus, T. and D. Riera-Crichton, (2015). Real Exchange Rate Volatility, Economic Growth and the Euro, Journal of Economic Integration, 30: 148-171.

Javorcik, B. S. (2004). Does Foreign Direct Investment Increase the Productivity of Domestic Firms? In Search of Spillovers through Backward Linkages. American Economic Review, 94(3), 605-627.

Jones, B., (2002). Economic integration and convergence of per capita income in West Africa, African Development Review, 14, pp. $18-47$.

Jooji, I.T. and C.B. Oguchi, (2017). Financial impropriety as a catalyst to economic recession: The Nigerian experience. A paper presented at the 2nd international conference on enhancing democracy, security, development and Nigerias foreign relations in a globalize world.

Kalaitzoglou, I. and B. Durgheu, (2016). Financial and Economic Growth in Europe: Is the Euro Beneficial for All Countries? Journal of Economic Integration, 31, pp. 414-471.

Kamau, N. L., (2010). The impact of regional integration on economic growth: empirical evidence from COMESA, EAC and SADC trade blocs, American Journal of Social and Management Sciences, 1, pp. 150-163.

Kizito Uyi Ehigiamusoe and Hooi Hooi Lean, (2018). Do economic and financial integration stimulate economic growth? A critical survey. Economics Discussion Papers, No 2018-51, Kiel Institute for the World Economy. 
Klein, M. W. and G. P. Olivei, (2008). Capital Account Liberalization, Financial Depth, and Economic Growth, Journal of International Money and Finance, 27, pp. 861-875.

Klofat, A., (2017). Corporate Tax Rates and Regional Integration: Evidence from Transition Countries, Journal of Economic Integration, 32, pp. 1-34.

Konig, J., (2015). European Integration and the Effects of Country Size on Growth, Journal of Economic Integration, 30, pp.501531.

Levene, H., (1960). Robust testes for equality of variances in Contributions to Probability and Statistics. 278-292. Stanford Univ. Press, Palo Alto, CA. MR0120709

Levine, R., (2001). International Financial Liberalization and Economic Growth Review of International Economics, 9, pp. 688702.

Levine, R., (2001). International Financial Integration and Economic Growth. Journal of International Money and Finance, 21, pp. 749-776.

Lopez-Cordova, E. and M.M. Moreira, (2003). Regional integration and productivity; the experience of Brazil and Mexico. A working paper of institute for the integration of Latin America and the Caribbean IDB-INTAL

Mann, K., (2015). The EU, a Growth Engine? The Impact of European Integration on Economic Growth in Central Eastern Europe, FIW Working Paper, No. 136,

Masten, A. B., Coricelli, F. and I. Masten, (2008). Non-linear growth effects of financial development: Does financial integration matter? Journal of International Money and Finance, 27, pp. 295-313.

Medee, P. N. \& N. Ikue-John, (2017). Determinants of Foreign Direct Investment in ECOWAS Region: A System GMM Approach. African Journal of Applied and Theoretical Economics (AJATE) Special Edition. Department of Economic Uniport, 295-309.

Mevel, S., deAlba, J. M. and N. Oulmane, (2016). Optimal Regional Trade-Integration Schemes in North Africa: Toward a ProIndustrialization Policy, Journal of Economic Integration, 31, pp. 569-608.

Olubusoye, O. E., A. S. Salisu, \& S. O. Olufin, (2015). Apply Panel Data Analysis. Center for Econometric and Allied Research (CEAR), 1-135.

Roy, A. and S. K. Mathur, (2016). Brexit and India-EU Free Trade Agreement, Journal of Economic Integration, 31, pp. 740-773.

Rajan, R. G., L. Zingales, (2003). The great reversals: the politics of financial development in the twentieth century. Journal of Financial Econ. 69; 5-50.

Schonfelder, N. and H. Wagner, (2015). The impact of European integration on institutional development. Journal of Economic Integration, 31, pp. 472-530.

Schularick, M. and T. M. Steger, (2010). Financial integration, investment, and economic growth: evidence from two eras of financial globalization, The Review of Economics and Statistics, 9, pp. 756-768.

Shen, C. H., and C. C. Lee, (2010). What Makes International Capital Flows Promote Economic Growth? An International CrossCountry Analysis, Scottish Journal of Political Economy, 57, pp. 515-546.

Soete, S. and J Van Hove. (2017). Dissecting the trade effects of Europe's economic integration agreements, Journal of Economic Integration, 32, pp. 193-243.

West African Monetary Institute (WAMI), (2015). WAMZ Trade Integration Report. Accra, Ghana: West African Monetary Institute. 